\title{
FAKTOR-FAKTOR YANG MEMPENGARUHI RENDAHNYA KECAKAPAN BERBICARA MAHASISWA PROGRAM STUDI BAHASA INGGRIS
}

\author{
Erny Selfina N. Hambandima, Tans Feliks, \& Josua Bire \\ e-mail: coolernye@gmail.com \\ Universitas Nusa Cendana, Kupang, Nusa Tenggara Timur
}

\begin{abstract}
Abstrak: Tujuan utama penelitian ini adalah untuk mengetahui faktor-faktor yang mempengaruhi rendahnya kecakapan berbicara mahasiswa Program Studi Bahasa Inggris, Fakultas Keguruan dan Ilmu Pendidikan, Universitas Kristen Artha Wacana Kupang Tahun Akademik 2013/2014. Penelitian ini dilaksanakan bagi mahasiswa semester IV yang sudah lulus mata kuliah Speaking Satu, Speaking Dua dan Speaking Tiga. Sebagai responden adalah dua puluh orang mahasiswa/i yang dipilih berdasarkan rentangan nilai kelulusan terendah ke atas. Hasil penelitian ini menunjukkan, ada dua belas faktor yang berpengaruh terhadap rendahnya kecakapan berbicara mahasiswa Program Studi Bahasa Inggris, Fakultas Keguruan dan Ilmu Pendidikan, Universitas Kristen Artha Wacana Kupang Tahun Akademik 2013/2014. Kedua belas faktor itu adalah psikologi, kedua faktor, rendahnya perbendaharaan kata, tidak adanya teman berbicara Bahasa Inggris, tekanan dalam Bahasa Inggris, lemahnya penguasaan tata Bahasa Inggris, kepribadian mahasiswa/i, pengaruh bahasa ibu, penampilan dosen/guru, metode mengajar para dosen/guru, lingkungan, motivasi belajar, silang budaya Bahasa Indonesia dengan Bahasa Inggris.
\end{abstract}

Kata kunci: analisis, faktor-faktor, pengaruh, rendahnya kecakapan berbicara.

\section{FACTORS AFFECTING POOR SPEAKING SKILLS OF THE ENGLISH DEPARTMENT STUDENTS}

\begin{abstract}
The main purpose of this research is to find out the factors affecting the poor speaking skill of semester four students at the English Department, Faculty of Teachers Training, Artha Wacana Christian University, Kupang. The research was conducted in the Academic Year 2013/2014 to the fourth semester students who had passed the lectures of Speaking One, Speaking Two and Speaking Three. The participants of the research were the students with the low marks ranked from the lowest level where twenty students were taken as the research subjects. The research result shows that there are twelve factors affecting the students' poor speaking skills: psychological factors, poor vocabulary-related factor, peer-related factors, pronunciation related factors, grammar related factor, personality factor, L1 interference related-factor, teacher-related factor, teacher's poor teaching method, environmental factor, motivation factor, and cross-cultural factor. Those are the main factors that have contributed to the speaking skills.
\end{abstract}

Keywords: analysis, factors, affecting, poor speaking skill.

\section{INTRODUCTION}

It is a fact that English is a world-wide language used for international means of communication which has been taught as a foreign language in our country, Indonesia, from the level of junior high school, even elementary school up to tertiary level. As a means of communication, the role of English is quite important that it has become our national concern.

The important role of English to our nation is obviously through the changes of one curriculum to another, English teaching methodology has become the main issue of strengthening the teaching strategies with the core purpose of enabling Indonesian school graduates to master and use English once they finish school, providing English will help them open up their communication to the world. Brown (2001:268269) suggests that good fluency represents the main characteristic of natural communication, thus, it should be given more weight in the teaching of speaking. The government of Indonesia, through the Department of education, has been so far trying hard to raise Indonesian high school graduates' English competence, but in fact most of our graduates cannot compete in job-seeking and job-creating providing they do not have strong English competence.

As it is understood this situation must have been resulted by poor English competence the students have acquired after finishing their study at university varies from one person to another. This attracts the 
writer's intention that makes the writer interested in finding out what factors that may have influenced the Indonesian English learners have poor speaking skill after being graduated from university level. This condition might have been influenced by the English teaching method or English language learners do not realize the important role of English for their future or learners of English only learn English to obtain a degree where they might be good at writing but poor in speaking or learners have lack of vocabulary so that they can hardly express themselves in terms of verbal communication.

The writer feels interested in finding out the factors which must have influenced students' English competence when they are graduated from senior high school or even from the tertiary level. In the last three years (2010 - 2012), being a lecturer at Kupang Artha Wacana Christian University, the writer has carried out a kind of entrance tests to new comers who chose English language as their major with the total numbers of test takers ranged from 35 (thirty five) to 40 (forty). The result showed that only few students were able to do the test fairly good while most of them failed to express themselves in English even at the very basic level. Most students came to university with very limited vocabulary that barred them from being able to basically express themselves in English. In this context Garrett (1986:46) asserts that;

Many students learn vocabulary and try to put many words together to create a proper sentence. It amazes that how many words some of my students know, but they didn't study phrases. When children learn a language, they learn both words and phrases together. Likewise, you need to study and learn phrases. If you know 1000 words, you might not be able to say one correct sentence. But if you know one phrase, you can make hundreds of correct sentences. If you know 100 phrases, you will be surprised at how many correct sentences you will be able to say. Finally, when you know only a 1000 phrase, you will be almost a fluent English speaker

It is true that being a human we can say something in a language because we know the meaning of the words we use in expressing ourselves. In fact if words are learnt and used individually they will be leading us to lexical meaning which most of the times create ambiguous meanings or even worse have no meaning at all. Words make meanings in their context so they must come in phrases or chunks. Each phrase or chunk consists of more than one word and they are inseparable. When the words in a phrase or a chunk are separated then the individual word will change its meaning. It is a fact that students tend to translate word by word according to what exists in the dictionary instead of understanding words in terms of phrases or chunks. "To catch a cold" could be translated as menangkap dingin" instead of "sakit demam or pilek, flu" to the contrary students would say "I enter wind" when he / she means to say Saya masuk angin ( to catch a cold ).

To the writer's first-hand experience many of our graduates have difficulties in expressing themselves where the writer sometimes faces and answers questions being asked by a great number of employees (bankers, government officers, business people etc) such as I can understand what people say "in English" but I can hardly answer them, why? I can read and understand simple English articles but I find it very difficult for me to write, why? From the two queries raised we can see that our graduates have some basic listening and reading (receptive language skills) but unfortunately they have poor speaking and writing (productive language skill). Ellis (198:84) emphasizes the statement above as follows:

Reading and listening are NOT enough. Reading, listening and speaking are the most important aspects of any language. The same is true for English. However, speaking is the only requirement to be fluent. It is normal for babies and children to learn speaking first, and to become fluent before starting to read and write. So its natural order is listening, speaking, reading then writing.

The statement above leads to language in speech. It is undeniable that reading, writing and listening are parts / skills of language but speaking has greater role or function in our daily life. Like a child, babies or children firstly listen to parents or friends talking then they pick up words. They then automatically make them meaningful by which in the future when they grow up all words they have picked up will be used in their speaking. Once they are grown up reading and writing get to be introduced when they are at school. Langacker (1968 : 13) in his book " Language and Its Structure" states that children display an amazing ability to become fluent speakers of any language consistently spoken around them. Every normal human child who is not reared in virtual isolation from language use soon comes to speak one or more languages natively.

In some informal occasions the writer, on one hand, was involved in some dialogues and conversations with students where she found out that to some students English is an interesting and enjoyable subject. That is why the students feel interested 
in learning it. They have a good understanding of the function of English as a tool of international communication. They are encouraged to have a good competence of English for their lives. On the other hand the writer also finds out that most students have no clear idea why they study English, some believe that English is not an interesting subject to study, they do not see the real function of English in their lives. These types of learners (students) have very low motivation to achieve their goal of studying English. They come to university with a hope to become English teachers one day, their parents do not have idea what their children are going to be. So it is true that the natural order of language skills are undeniably listening, speaking, reading and writing with speaking plays a great role in oral communication.

\section{METHOD}

In this study, the researcher purposively listed out students of fourth semester who have passed the lectures of Speaking One, Two and Three but with low marks ranged from the poorest level. From the list there are twenty students taken as the research subjects.

The instruments used in this research are interviews and observations. Interviews were carried out between two to three times for each respondent where the interview situation was set or conditioned to be friendly and open. Observations had been informally being carried out, while students at campus, since they took Speaking One, Speaking Two and Speaking Three lectures. At times, the writer by design informally observed the students by means of talking to them in English to find out what motivations they had got and what problems (if any) they had got while studying at the English Department. Some home visits to their dormitories or boarding houses were carried out to find out whether their living conditions supported their studies or not in terms of books, dictionaries, reading sources such as novels, articles availabilities.

\section{RESULT AND DISCUSSION}

All data consist of observations and interviews. Interviews were carried out between two to three times for each respondent where the interview situation was set or conditioned to be friendly and open. Observations had been informally being carried out, while students at campus, since they took Speaking One, Speaking Two and Speaking Three lectures. The researchers concluded that the data collected here is descriptively analyzed and interpreted, based on
Harmer (2007) as a process and it is meant to answer the components in this data analysis.

In this part, the writer analyzes the data from interviews results. There are four items that the writer is going to present here. It starts with the leading question "Do you like to speak English?" The expected responses from the students are 'Yes or No' where each of the questions is expected to be completed with students' own descriptions for their reasons. From the interview carried out in the second and the third week of June 2014 the writer found out that there were nineteen out of twenty students who liked to speak English but they had various problems that barred their intentions to speak in English. Each of them had different comments and ideas on what problem they encountered in speaking in English. There was only one student who did not like to speak English because she did not want to be an English teacher but she would rather find another job than being a teacher.

Those who like English state the following reasons: (1) nine students said that they liked to speak English because they wanted to be English teachers and or tour guides as well; (2) Two students stated that being an international language English helped to open the chance for them to communicate internationally; (3) Three students really liked English and were very interested in seeing other friends talking in English; (4) One student enjoyed speaking in English and he was also jealous of seeing another people speaking in English; (5) One student did not have any description when questioned; (6) Two students also used English and liked to use it in daily communication; and (7) One student stated that she enjoyed speaking English to smoothen her speaking fluency.

Despite those positive reasons, their English speaking skill is generally poor as shown by their Speaking One, Speaking Two and Speaking Three scores. Such a poor speaking skill has been influenced by the following factors:

\section{Psychological Factor}

As English is taught as a foreign language in our country it is uncommon to most of our students to use English in their lives. Students are shy to use English in their daily communication. Psychologically they are discouraged if someone laughs at the mistakes they are making when they are talking to their friend/s in English. Five students said that they never used English in speaking as they got embarrassed with people listening and seeing them speaking English. One student talked with friends when at home (in their dormitory only) and never spoke out of home because she was afraid of surrounding listeners listening and 
laughing at her. Six students uttered they were not confident to speak in English as they were afraid of making mistakes and being laughed at. Two students found themselves having mental problem that is they were not brave to speak English. Two students said that they felt embarrassed to speak in English

\section{Poor Vocabulary-Related Factor}

The second problem encountered by students is vocabulary. Students often search for an appropriate word to speak. This case happens to a student who said it was quite difficult for herself to determine proper word/s to be correctly used in an English speaking conversation. Furthermore she stated that English had different words diction and speakers had to selectively choose the words to construct a meaningful, understandable utterance in a conversation. She emphasized that each word had its own contextual meaning which had to be used in different context for different situation. She found it hard for her to use words correctly in their precise context. There were also fifteen respondents stated that they were lacked of vocabulary which made them hard communicate verbally in English. They got stuck when they tried to speak to their speaking partners for they only had a very limited stock of vocabulary

\section{Peer-Related Factor}

It is hard for students to find peer speakers to practice their speaking with. Seven students admitted that they rarely practiced speaking for they did not have speaking partners. They found their friends were too shy to use English at home (out of English classes). One respondent stated she rarely communicated in English since she did not have friends to talk to. Another student also rarely used English for daily communication because her talking partner tended to respond in Indonesian language rather than English. Two students sometimes practiced English speaking at campus but instead of responding to them in English their friends turned up to discourage them by saying that they were showing off. Given language is speech and speech needs practice the rareness of friends to practice English with both at the university and at home has become a barrier for students to increase their speaking competence.

\section{Pronunciation-Related Factor}

In order to convey meaning, students must have the knowledge of words and sentences. They must understand how words are segmented into various sounds, how sentences are stressed in particular ways. This was the case the interviewed students had been facing so far. They said that they had difficulties in producing sounds of English as well as the words stress. Nine students uttered that they were afraid to speak English as they realized they had bad pronunciation. Two students had similar difficulty in speaking English where they said they always made errors in word stressing.

\section{Grammar-Related Factor}

Even though some learners have learnt the language at high school they are still unable to construct sentences without grammatical errors. One respondent admitted that her speaking was bad due to grammatically she made a lot of mistakes when she talked in English. Two students realized they were not confident to speak and or to write as they understood they had broken grammar of English. Being poor in grammar mastery drives students away from using English to communicate verbally in their daily lives. It is a fact that grammatical competence enables speakers to use and to understand the structure of English-language accurately and unhesitatingly, which contributes to their fluency but English has been taught to pass the written final examination.

\section{Personality Factor}

A prominent problem encountered by the learners in language acquisition process is learner inhibition. This must have made the students worried about making mistakes in using English to converse, being criticized or losing faces in front of the rest of a class or in public. Twelve students are recorded to have had such kind of personality in this research. Four students were afraid of being laughed at when knowing that they were making mistakes in talking in English. This results in their speaking performance where they make a lot of mistakes even though they have a very good knowledge where sometimes such situation makes them totally keep silent. To the writer's first-hand experience most students with low speaking competence are afraid or probably shy of making mistakes in speaking, and the result was that four students said that they were shy. They were not confident enough to express themselves in English. Another reason according to students interviewed is that the point of learning English is to pass the examination not to use it in daily communication. Eight students stated that they studdied English to get mark instead of using it for speaking. One student said she was focusing on getting passing marks so that she could pass the examination.

\section{L1 Interference-Related Factor}

Students generally tend to make an excessive use of their mother-tongue when it comes to the activities in productive skills namely- speaking and writing. When they were facing the interview 
questions, they immediately started thinking about the topic of conversation in their mother tongue, framing what they wanted to say in their mother-tongue and then translated it into English, which often results in mistakes. During the interview process the writer found out that there were eighteen students who directly translated from Indonesian into English. Thus, the students often tended to make use of their mothertongue which results in losing the motive of learning the language and lack of practice.

The writer also discovered that when students were asked to write a short discourse or perform a conversation in English, they tended to write it firstly in their mother tongue and of course using lexical translation, using dictionary to convert their writing into English which ended up to meaningless writing providing word by word translation does not make meaningful discourse. For example; when using dictionary one will tend to lexically translate the Indonesian utterance of "Saya masuk angin" into English translation of "I enter wind" instead of "I catch a cold". In relation to speaking competence two students found problems with the local dialect interference. When they were asked to answer the interview questions they could hardly response to it since they had to translate each word from their mother tongue into English.

\section{Teacher-Related factor}

Fifteen students said that they had problem facing their lecturer/s. The fifteen students answers indicate that there are students who are not brave or confident enough coping with unfamiliar teachers / lecturers performances. They tended to keep silent instead of saying something wrong in front of an unfriendly lecturer. This situation makes them scared to use English for daily communication (in terms of speaking. built a good rapport with them). Such situation can be easily created by starting with simple and easy tasks. When it is created it will help to encourage the slow students to participate in the activity and boost their morale. The next important aspect is to build confidence in the learners. Once the teacher establishes a good rapport with the learners, it will build up the students' confidence. Gradually increasing the difficulty level will sharpen their knowledge thereby improving the learners. Minimizing teacher talk time and maximizing learners talk time will also encourage the learners. The writer found out that the students got suggested or motivated by the lecturers when the lecturers kept asking them to practice speaking in their daily lives even make mistake, said two students. Instead of correcting the mistakes, the lecturers could go for peer correction which would encourage them to come out of inhibition. Lecturers/teachers are hoped to be a guide, a mentor and a facilitator.

\section{Factor Related to Teacher's Poor Teaching Method}

Lecturers play important roles in the class. They must function as leaders of the class, motivators of the class who are able to create a friendly teaching and learning atmosphere to give learners self-confidence building. Eighteen students realized that various kinds of teaching methods such as individual work, group work, games, describing pictures, telling stories of daily activities, debating, reading text orally would make them interested in using English to speak. One student said he was asked to search words in the dictionary after which the selected words were put into sentences and then the formulated sentences sent to friends via short messages services. Such kinds of teaching varieties would raise students motivation to speak in English said the eighteen students. Two students said that only a couple of lecturers varied their teaching method while most lecturers just monotonously sticked themselves to what had been prepared before coming to class which made them bored in the speaking class and they were lazy to practice speaking in English.

\section{Environmental Factor}

Building rapport and good relation within the learners and the lecturers is essential to create a friendly learning atmosphere. Fifteen students said that when lecturers were friendly teaching them speaking they felt happy and free to express themselves. When the teaching and learning environment is harmonious where lecturers give opportunity to students to practice speaking without being discouraged whenever they make mistakes will give a very positive impact on increasing students' speaking competence. Making students feel at home whenever they are at school or university campus will put aside students' shyness so that they are brave enough to express themselves both in class and outside the class using English as a medium of interaction. In addition five students said some teachers / lecturers did not seem familiar to students. Such condition makes students felt uneasy, shy and even scared to talk while at campus. The five students uttered that a few lecturers looked scary that made them scared to talk.

\section{Motivation Factor}

This lack of confidence prevents students from learning the speaking skills. The writer found out that students failed to master the English speaking skill since they feel it is impossible for them to do it. They 
easily give in and do not want to continue learning whenever they fail in expressing their ideas even in a very simple statement. They seem impatient and have very little confidence and motivation in coping with some barriers that they come across in learning. Out of the twenty respondents the writer found out that when interviewed students said they felt embarrassed or lack of inner motivation to speak English as the consequence of being afraid of making mistakes. In this case eleven students were listed as being too nervous to speak. The feeling of making mistakes becomes a nightmare in speaking. It has to be erased from their mind and they must be motivated to become brave students to learn from mistakes.

Following are students' comment about the lecturers' motivation to the students; (1) four students were suggested to keep practicing speaking in their daily lives without worrying about what mistakes they would make. (2) Three students were suggested to build up vocabulary by means of memorizing new vocabularies to enrich his stock of vocabulary (3) Ten students were encouraged to keep reading to open up their minds as well as to build up their vocabulary stock (4) Three students were encouraged to spend more time to read a lot and to listen to music to enlarge their vocabulary.

\section{Cross-Cultural Factor}

Oral communication involves a very powerful non-verbal communication system, which sometimes contradicts the messages provided through the verbal listening channel. Lack of knowledge of the nonverbal communication system of a target language usually results in the inability to pick up non verbal cues by L2 learners, which often results in misunderstanding. One thing to be noted that some body movements are different from one language to another, that is why learners of English language are required to learn the English speaking culture as well. A student said she never used gestures as she was afraid that her instruction in gestures gave wrong meaning providing English had different gestures compared to Indonesian. She was not certain to use gestures whenever she came across difficult words/phrases/ chunks.

Thirteen students realized that when they did not know what words/phrases/ chunks to use in verbal communication they used gestures or nonverbal communication in expressing their feeling or to emphasize the meaning of their expression. Whenever a creative speaker comes across a deadlock where he / she cannot express his / her idea in verbal communication he / she can make use of body language, kinemes (facial expressions, etc). Such alternative is a great way out to get away when one is lack of certain vocabulary in verbal communication.

\section{CONCLUTION}

Based on the result of the analysis and discussion, the writer found that In general, the fourth semester students who have finished their Speaking One, Two and Three classes really like to speak English but they have difficulties in speaking. Data analysis shows that nine students have got the same dream that they want to become English teachers as well as a tour guides. Most of the students said that they found difficulties in communicating using speaking English as a means of communication affected by the following factors:

The first is psychological factor; students find themselves shy to speak when they are in campus because they are afraid of being laughed by listeners or whoever nearby them when the conversation takes place. The second is poor vocabulary-related factor; lack of vocabularies, in fact, makes the students not confident to use English for communication since they do not know a lot of English words, Peer-related factor is the third hindrance; students do not use English for their daily communication since they do not have friends to talk to in English while out of campus. The fourth is pronunciation-related factor; students have difficulties with pronunciation. They have difficulties in producing sounds of English as well as the words stress. Students realize they have bad pronunciation especially in word stressing. The fifth is grammarrelated factor; making a lot of grammatical mistakes when students speaking in English makes not confident to speak and or to write as they understand they have broken grammar of English.

The sixth is personality factor; students study English with an intention to get marks to pass the examinations and they do not care much about whether they can speak English or not. Students are also afraid of making mistakes in speaking in English at home or in the community for their friends or colleagues sometimes laugh at the mistakes they make when they are talking in English. L1 interferencerelated is the seventh factor; students tend to use direct translation where every word from Indonesian language is directly translated into English. They conceptualize the word/s in their mother tongue then transfer it into English. The eighth is teacher-related factor; students are noted to have problem facing their lecturer/s. Students answers indicate that they are not brave or confident enough coping with unfamiliar teachers / lecturers performances inside or outside 
the class. The ninth point is factor related to teacher's poor teaching method; students admitted that various kinds of teaching methods such as individual work, group work, games, describing pictures, telling stories of daily activities, debating, reading text orally would make them interested in using English to speak. Varying the teaching method makes students attracted in using English in daily speaking where it will raise students' motivation to speak in English. Only a couple of lecturers vary their teaching method while most lecturers just monotonously base themselves on what have been prepared before coming to class. Such situation makes students bored with the speaking class and they were lazy to practice speaking in English. Environmental factor is the tenth point; good relation within the learners and the lecturers is essential to create a friendly learning atmosphere. Students said that when lecturers were friendly teaching them speaking they felt happy and free to express themselves. When the teaching and learning environment is harmonious where lecturers give opportunity to students to practice speaking without being discouraged whenever they make mistakes will give a very positive impact on increasing students' speaking competence.

The eleventh factor is related to motivation; students feel embarrassed or lack of inner motivation to speak English as the consequence of being afraid of making mistakes. Students get too nervous to speak for they have the feeling of making mistakes that becomes a nightmare in speaking and the last is cross-cultural factor, students use gestures to communicate whenever they do not certain words to say when they are talking in English. Whenever they get stuck in expressing themselves using English words they quickly shift the conversation from verbal communication to using gestures.

\section{REFERENCE}

Arsyad, A. (2003). Media pembelajaran. Jakarta: Rajawali Press.

Aungwatanakun, S. (1994). English teaching methodolo$g y$. (2nd). Bangkok: Chulalongkorn University Press.

Brown, H.D. (1994). Teaching by principles: An interactive approach to language pedagogy. San Francisco State University. Prentice Hall Regents.

Brown, H.D. (2000). Principles of language learning and teaching. Pearson Education Ltd.

Budi, A. (2013). A Study on code switching used by the teachers of english at SMAK Giovanni Kupang in the school year 2013/2014. Unpublished Thesis.
Kupang: Widya Mandira Catholic University.

Davis, R.S. (1997). Comics: A multy-dimensional teaching aids in integrated-skills classes. Nagoya City University.

Devine, T.G. (1986). Teaching reading comprehension: From theory to practice. Allyn and Bacon

Flood, J. \& Lapp, D. (1991). Reading comprehension instruction. New York. Macmillan.

Gough, P. (1972). “One second of reading”. In J. F. Kavanagh, and I. G. Mattingly, (Eds.) Language by ear and by eye (pp. 85-102). Cambridge: MIT Press.

Harmer, J. (2007). The practice of english language teaching. Pearson Education Ltd.

Hughes, A. (1989). Testing for language teacher. Cambridge: Cambridge University Press.

Lado, R. (1961). Language testing: Speaking a foreign language. George Town University.

Latuheru, D.J. (1988). Media pembelajaran dalam proses belajar mengajar masa kini. Depdikbud Dirjen Dikti. Proyek Pengembangan Lembaga Pendidikan Tenaga Kependidikan.

Heinich, R. (1982). Instructional media and the new technology of instruction. New York: John Wiley and Sons, INC. Ottawa.

Hughes, R. (2011). Teaching speaking. New York.

Leki, L. and Carson, J. (1994). Students' perceptions of EAP writing instruction and writing needs across the disciplines. TESOL Quarterly.

Parus, H. (2013). A study on the teacher and students talk in classroom interaction of the tenth class students of SMA Muhammadiyah Kupang in the school year 2013/2014. Unpublished Thesis. Widya Mandira Catholic University. Kupang.

Puryanti. (2013). “Designing task-based module for teaching speaking (A research and development at the first semester of tenth grade students of SMA Negeri 1 Kroya in the school year of 2012/2013)". Thesis. Surakarta.

Oradee, T. (2012). Developing speaking skills using three communicative activities (discussion, problem-solving, and role-playing). November Vol. 2, No.6, November 2012.

Richard, J.C. (2006). Communicative language teaching today. New York: Cambridge University Press.

Rohani, A. (1997). Media instruksional edukatif. Jakarta; Rineka Cipta

Sadiman, A.F. (2006). Media pendidikan: Pengertian, pengembangan, dan pemanfaatannya. Jakarta: Raja Grafindo Persada.

Smith, A.D. (2008). "The role of the divination record in the emergence of chinese literacy". Dissertation. 
University of California.

Smith, M. \& Knowles, E. (1997). The reading connection: Bring parents, teachers, and librarians together. USA: Libraries Unlimited, INC.

Shumin, K. (2002). "Factors to consider: Developing adult EFL students' speaking abilities" in Methodology in Language Teaching. Cambridge: Cambridge University Press.

Sugiyono. (2010). Metode penelitian pendidikan pendekatan kuantitatif, kualitatif, dan RED. Bandung.

Susilana, R. (2009). Media pembelajaran: Hakikat pengembangan, pemanfaatan, dan penilaian. Bandung: Wacana Prima.

Ur, P. (1996). A course in language teaching. Cambridge: Cambridge University Press.
Wahono. (2006). Komik sebagai media informasi. http://Media-ide.bajingloncat. com/2006/04/27/komik informasi. Retrieved on January 2004.

Anonymous. (2007). Komik. http:/ /id.Wikipedia.org/ Wiki/Komik. Retrieved on January 2014.

Agil, K. (2012). Teaching speaking through visual media. Art-corners.blogspot.com/2012/06.html, retrieved on January 2014.

Neelu. (2010). Audiovisual aids. http://avaudiovisualaids.blogspot.com. Retrieved on January 2014.

Patil,V. Importance of audio - visual aids in teaching methodology. http://www.articlesbase.com/ tutoringarticles / importance-of-audio-visual-in-teaching-methodology-3667855.html Nov 15, 2010. Retrieved on 20 October 2014. 